FIU Law Review

Spring 2009

\title{
Government Investment in Banks: Creeping Nationalization or Prudent, Temporary Aid?
}

\author{
Lissa L. Broome \\ University of North Carolina at Chapel Hill School of Law
}

Follow this and additional works at: https://ecollections.law.fiu.edu/lawreview

Part of the Other Law Commons

Online ISSN: 2643-7759

\section{Recommended Citation}

Lissa L. Broome, Government Investment in Banks: Creeping Nationalization or Prudent, Temporary Aid?, 4 FIU L. Rev. 409 (2009).

DOI: https://dx.doi.org/10.25148/lawrev.4.2.5

This Article is brought to you for free and open access by eCollections. It has been accepted for inclusion in FIU Law Review by an authorized editor of eCollections. For more information, please contact lisdavis@fiu.edu. 


\title{
Government Investment in Banks: Creeping Nationalization or Prudent, Temporary Aid?
}

\author{
Lissa L. Broome*
}

\section{INTRODUCTION}

In 2008, twenty-five banks failed, more than in any year since $1993 .{ }^{1}$ The pace of bank failure has accelerated in 2009, with the 2008 total of twenty-five matched by mid-April. ${ }^{2}$ Three of the four largest U.S. banking institutions were so at risk that one-Wachovia — was acquired by Wells Fargo, a smaller institution, ${ }^{3}$ and two - Citigroup and Bank of Americawere forced to request governmental investments in excess of the initial government investments they received under the Troubled Asset Relief Program (TARP). ${ }^{4}$ The Federal Deposit Insurance Corporation's (FDIC) ratio of reserves-to-insured deposits slipped to just $0.4 \%$ as of year-end 2008 , well below the statutory minimum of $1.15 \%$ and the lowest level since 1993. The aggressive responses to the crisis by Congress, the Treasury Department, the Federal Reserve Board of Governors (FRB), and the FDIC to help banks improve their capital positions and liquidity have dra-

* Wachovia Professor of Banking Law; Director, Center for Banking and Finance, University of North Carolina at Chapel Hill School of Law. Thanks to Eamonn K. Moran, Research Associate, Center for Banking and Finance for valuable research assistance, and to Lawrence Baxter, Adam Feibelman, Eamonn Moran, and Saule Omarova for helpful comments on earlier drafts of this article.

1 Joe Adler, Two More Failures Brings 2008 Tally to 25, AM. BANKER, Dec. 15, 2008, at 16; see also FDIC, BANK FAILURES \& AsSISTANCE, (2008) http://www.fdic.gov/bank/historical/bank/2008/index.html. Moreover, one of those failed banks Washington Mutual (WaMu) - was the largest bank failure in history. The WaMu failure was resolved at no cost to the FDIC, however, J.P. Morgan Chase \& Co. purchased its banking operations for \$1.9 billion. Joe Adler, Success with Failures, AM. BANKER, Dec. 29, 2008, at 1.

See http://www.fdic.gov/bank/individual/failed/banklist.html.

3 As of June 30, 2008, Wachovia's assets stood at $\$ 812.4$ billion, thirty-three percent larger than Wells Fargo's $\$ 609$ billion in assets. See Bank and Thrift Holding Companies with the Most Assets on June 30, 2008, AM. BANKER, Jan.15, 2009.

4 Citigroup and Bank of America each received additional TARP funds beyond that in the initial Capital Purchase Program. The government's investment in preferred stock in each institution now stands at $\$ 45$ billion. See infra text accompanying notes 26 and 29.

5 Joe Adler, FDIC's New Assessment Lambasted as Unfair, AM. BANKER, Mar. 2, 2009, at 1. 
matically altered the liability/equity sides of bank balance sheets. ${ }^{6} \quad$ This unprecedented government assistance to prevent widespread bank failure and to provide support for those institutions "too big to fail" underscores the vital role that banks play in our economy.

This Article explores government investment in banks and discusses some of the implications of these investments. In Part II., the government investment in bank stocks during the current financial crisis are detailed. Part III. recounts the government's prior extensive investment in preferred stock of banks during the Great Depression through the Reconstruction Finance Corporation (RFC), and the government's equity investment in one large bank, Continental Illinois National Bank, to prevent its failure in 1984. The implications of government investments in banks are explored in Part IV., first through the lens of history with reference to the RFC and Continental Illinois, and then considering the current objections and concerns raised about creeping government nationalization of banks. Finally, the article poses the questions yet to be answered about current government investments before we learn whether the government will be able to return the ownership of financial institutions fully to private hands and without significant cost to the public treasury as it was able to do in the prior two cases of government ownership examined in this article.

\section{GOVERNMENT INVESTMENTS IN BANKS DURING THE CURRENT FINANCIAL CRISIS}

Congress' initial legislative response to the financial crisis was the Emergency Economic Stabilization Act of 2008 (EESA), enacted on October 3, 2008. The $\$ 700$ billion in funds authorized by Congress in EESA to assist in the financial crisis clean-up, labeled "Troubled Asset Relief Program" (TARP), were quickly diverted by then-Treasury Secretary Henry Paulson from buying troubled mortgage-related assets held by banks to purchasing preferred, non-voting stock in banks under what is now called the Capital Purchase Program (CPP). ${ }^{7}$ The initial tranche of TARP funds was $\$ 350$ billion, with $\$ 250$ billion specifically set aside for bank stock purchases. A second bank investment program, the Targeted Investment Program (TIP), was announced on November 23, 2008, and has been used to fund additional preferred stock investments in Citigroup and Bank of America beyond the initial CPP investments. The Senate authorized the second tranche of TARP funds on January 15, 2009, prior to the change in

6 These changes are described in Lissa L. Broome, Perspectives on the Financial Crisis: Extraordinary Government Intervention to Bolster Bank Balance Sheets, 13 N.C. BANKING INST. (forthcoming 2009).

7 See Press Release, U.S. Treas. Dept., Pub. No. HP-1207, Treasury Announces TARP Capital Purchase Program Description (Oct. 14, 2008), http://www.treas.gov/press/releases/hp1207.htm [hereinafter TARP Capital Purchase Program Description]. 
administration $^{8}$ pursuant to a request from President Bush made at the urging of President-elect Obama. ${ }^{9}$ The new Obama administration announced on February 10, 2009, the Financial Stability Plan - its new name for TARP - that would fund additional bank stock purchases under a new program called the Capital Assistance Program (CAP).

\section{A. Capital Purchase Program (CPP) -TARP $1^{10}$}

The first tranche of funds released by Congress for the TARP amounted to $\$ 250$ billion, and all of it has been committed for CPP and TIP preferred stock purchases; as of March 31, 2009, \$235.8 billion had actually been disbursed. $^{11}$ Secretary Paulson deemed the CPP a more expeditious way to inject capital into the banking system than attempting to value and purchase troubled mortgage-related assets held by banks. Originally, Paulson strongly resisted government stock purchases, asserting that taking preferred stock in banks is "what you do when you have failure" and stating "[t]his is about success." was in stark contrast with the lead of other countries, including the United

8 Cheyenne Hopkins, House Passes Symbolic Tarp Block, AM. BANKer, Jan. 23, 2009, at 3 (the House voted to block the release of the second tranche of TARP funds, but the move was only symbolic since both chambers were required to block the funds and the Senate had approved the second tranche on January 15).

9 David M. Herszenhorn, At Obama's Urging, Bush to Seek Rest of Bailout Funds, N.Y. TimES, Jan. 12, 2009.

10 This section is substantially drawn from Broome, supra note 6.

11 Financial Stability OVERSight BoARD, QuARTERly RePORT to CONGRESS PURSuANT to SECTION 104(G) OF THE EMERGENCY ECONOMIC STABILIZATION ACT OF 2008 (for the quarter ending Mar. 31, 2009), http://www.financial stability.gov/latest/+g_042409.html; see also Mike Ferullo, Treasury Financing: Treasury Disclosed \$15 Billion in Funds to Banks Under Capital Purchase Program, 92 BNA BANKING REP. 131 (Jan. 20, 2009). The amount of preferred stock that the government purchased in any one institution could not be less than one percent of the institution's risk-weighted assets, and not more than the lesser of $\$ 25$ billion or three percent of risk-weighted assets. U.S. TREAS. DEPT., Program DESCRIPTIONS, CAPITAL Purchase Program (2009), http://www.treas.gov/initiatives/eesa/program-descriptions/cpp.shtml [hereinafter "Program Description"]. JP Morgan Chase, Citigroup, Wells Fargo, and Bank of America (following the consummation of its merger with Merrill Lynch) each received the maximum investment of $\$ 25$ billion. U.S. TREAS. DEPT., APPENDIX 1, FOURTH TRANCHE REPORT TO CONGRESS 1 (2009), http://www.treas.gov/initiatives/eesa/docs/Fourth-Tranche-Report-Appendix.pdf [hereinafter Fourth Tranche Appendix].

Such widespread government ownership of bank stock is not without precedent. The Reconstruction Finance Corporation, established in 1932, bought stock in 6,000 banks at a cost of $\$ 1.3$ billion, which would be approximately $\$ 200$ billion in today's dollars, and the government about broke even on the subsequent sale of bank stock to investors or back to the banks. More recently, in 1984, the United States took an eighty percent ownership stake in Continental Illinois National Bank, at the time the country's seventh largest bank. See Steve Lohr, Intervention is Bold, but Has a Basis in History, N.Y. TIMES, Oct. 14, 2008, at A1.

12 Edmund L. Andrews \& Mark Landler, White House Overhauling Rescue Plan, N.Y. TIMES, Oct. 12, 2008, at A1, available at http://www.nytimes.com/2008/10/12/business/12imf.html (quoting testimony before the United States Senate Committee on Banking, Housing and, Urban Affairs on September 23, 2008). 
Kingdom, Germany, France, Spain, and Italy. But, he soon did an about face, announcing the CPP on October 14, 2008. ${ }^{13}$

The Treasury Secretary's authority under EESA to use the so-called "bailout" funds to buy preferred stock is somewhat convoluted. The Secretary is authorized by EESA to "purchase, and to make and fund commitments to purchase, troubled assets from any financial institution." "Troubled assets" are defined to include the types of assets that most observers anticipated would be purchased - "residential or commercial mortgages and any securities, obligations, or other instruments, that are based on or related to such mortgages," 15 as well as "any other financial instrument that the [Treasury] Secretary, after consultation with the Chairman of the Board of Governors of the Federal Reserve System, determines the purchase of which is necessary to promote financial market stability."

The term "financial instrument" is not, however, defined in the statute. A colloquy on the floor of the House of Representatives prior to the House vote in favor of EESA addressed the scope of the term. Representative Barney Frank, Chairman of the House Financial Services Committee, confirmed that the scope of the assets that the government may purchase "is intended to include capital instruments of an institution such as common and preferred stock, subordinated and senior debt, and equity rights." Frank noted that the "authority to buy equity" was added to the EESA by the House and the Senate, and that the purpose of the expenditures "is not simply buying up the assets, it is to buy equity, and to buy equity in a way that the Federal Government will be able to benefit if there is an appreciation," 18 and "to enable financial institutions to begin providing credit again." infusions have the capacity to provide between ten and twelve times the amount of the initial government investment. ${ }^{20}$

As the CPP program was originally conceived, there were no specific requirements regarding how banks that received the government equity infusion should use it. The expectation by Treasury officials and perhaps

13 Press Release, U.S. Treas. Dept., Pub. No. HP-1206, Joint Statement by Treasury, Federal Reserve and FDIC (Oct. 14, 2008) http://www.treas.gov/press/releases/hp1206.htm; see also Broome, supra note 6.

14 Emergency Economic Stabilization Act of 2008, H.R. 1424, 110th Cong. § 101(a)(1) (2008). "Financial institution" is defined as "any institution, including, but not limited to, any bank, savings association, credit union, security broker or dealer or insurance company . . . having significant operations in the United States, but excluding any central bank of, or institution owned by, a foreign government." Id. §3(5).

$15 \quad$ Id. $\S 3(9)(\mathrm{A})$.

Id. $\S 3(9)(\mathrm{B})$ (emphasis added).

154 CONG. REC. H10763 (daily ed. Oct. 3, 2008) (statement of Rep. Frank) (emphasis added).

Id.

19 Id.

20154 CONG. REC. H10796 (daily ed. Oct. 3, 2008) (statement of Rep. Moran). 
Congress seems to have been that banks would use the additional capital to increase lending, when in fact much of it appears to have been used to shore up capital positions and, at least in one case, finance an acquisition of an institution that did not have its request for TARP funds honored. ${ }^{21}$ The Government Accountability Office (GAO), in its January 2009 report to Congress on the efforts of Treasury to address transparency and accountability issues, noted that Treasury had developed a monthly survey for the twenty largest CPP recipients that would provide data on new loan originations by categories, and data on the purchase of mortgage- and asset-backed securities. ${ }^{22}$ For all other institutions, the Treasury announced that it is working with the bank regulators to develop an approach to the analysis of the quarterly call report data for CPP institutions to determine lending activities at CPP institutions compared to lending activity at those institutions that did not accept CPP funds.

The statute did require that certain executive compensation arrangements for CPP recipients would be limited. ${ }^{24}$ In addition, banks receiving the investment money were required to sign a contract providing that the Treasury "may unilaterally amend any provision . . . to the extent required to comply with any changes after the Signing Date in applicable federal statutes. $" 25$ Some banks cited this open-ended commitment as the reason they elected not to apply for TARP money, have yet to decide whether to accept it, or have decided not to accept the funds. ${ }^{26}$

Institutions accepting preferred stock investments by the United States also are required to pay quarterly dividends to the United States of five percent per year for the first five years of the investment and nine percent per year thereafter. ${ }^{27}$ The institution may repurchase the preferred stock three years after its issuance for the purchase price plus accrued and unpaid dividends. ${ }^{28}$ A repurchase is not permitted unless the investment is replaced by an equivalent amount of private capital. The government also receives warrants to buy common stock at a market price equal to fifteen percent of its

21 See Joe Adler, Success with Failures, Am. BANKer, Dec. 29, 2008, at 1 (discussing PNC's purchase of National City after Treasury declined to provide TARP funds to National City as a standalone entity).

22 Gov't Accountability Office, Pub. No. GAO-09-296, Troubled Asset Relief Program: STATUS OF EFFORTS TO ADDRESS TRANSPARENCY AND ACCOUNTABILITY 19 (2009).

23 Id.

24 See U.S. Treas. Dept., Emergency Economic Stabilization Act, Executive COMPENSATION, http://www.treas.gov/initiatives/eesa/executivecompensation.shtml (last visited Feb. 8, 2009).

25 U.S. Treas. Dept., Securities Purchase Agreement, Standard Terms 35 (2008),

http://www.treas.gov/pres/releases/reports/spa.pdf.

26 See Katie Kuehner-Hebert, Approved for Infusions - But Hesitant, AM. BANKER, Jan. 8, 2009, at 1 .

27 See TARP Capital Purchase Program Description, supra note 7.

28 Id. 
preferred stock investment. ${ }^{29}$ The exercise price for the warrants is the common stock price on the date of the investment. ${ }^{30}$

B. Targeted Investment Program for Systemically Significant Institutions ${ }^{31}$

On November 23, 2008, the Treasury Department, FRB, and FDIC announced further actions to support Citigroup. ${ }^{32}$ This new effort included an additional \$20 billion investment in Citigroup preferred stock carrying an eight percent dividend, as opposed to the five percent dividend due to the Treasury during the first five years on its initial $\$ 25$ billion equity infusion. $^{33}$ Pursuant to this second extraordinary infusion of equity, the Treasury imposed some additional conditions. First, dividends on common stock are limited to one cent per share per quarter for three years unless the Treasury consents to additional dividend payments. ${ }^{34}$ Second, there are additional restrictions on executive compensation, ${ }^{35}$ and, third, Citigroup must adopt the FDIC's mortgage modification procedures developed in the conservatorship of IndyMac. Bank of America received a similar package of benefits, in large part because of its acquisition of loss-plagued Merrill Lynch, including another \$20 billion preferred stock investment, on January 16, 2009. ${ }^{36}$ These additional equity investments in Citigroup and Bank of America were pursuant to a new TARP program labeled the Targeted Investment Program (TIP). ${ }^{37}$ The purpose of TIP is to "foster market stability and thereby to strengthen the economy and protect American jobs, savings, and retirement security., ${ }^{, 38}$

29 Id.

30 Id. (the market price at investment is to be calculated on a 20-trading day trailing average).

31 See, e.g., Broome, supra note 6.

32 Press Release, FDIC, Pub. No. PR-125-2008, Joint Statement by Treasury, Federal Reserve, and FDIC on Citigroup (Nov. 23, 2008), http://www.fdic.gov/news/news/press/208/pr08125.html.

33 Id.

34 Id.

35 See text accompanying notes.

36 Press Release, FDIC, Treasury, Federal Reserve, and the FDIC Provide Assistance to Bank of America (Jan. 16, 2009), http://fdic.gov/news/news/press/2009/pr09004.html.

37 There are currently two other TARP programs in addition to the CPP and TIP. One, for Systemically Significant Failing Institutions, was used to provide $\$ 40$ billion to AIG in exchange for preferred stock and warrants. See Fourth Tranche Appendix, supra note 11. The second, announced in December 2009, is the Automotive Industry Financing Program in which $\$ 19.4$ billion (and an additional $\$ 4$ billion subject to certain conditions) has been committed to GMAC, GM, and Chrysler. Id.

38 Press Release, U.S. Treas. Dept, Treasury Releases Guidelines for Targeted Investment Program (Jan. 2, 2009), http://www.treas.gov/press/releases/hp1338.htm (listing five eligibility considerations that Treasury may consider in providing additional capital under this program). 
C. The Financial Stability Plan-TARP 2-and the Capital Assistance Program (CAP)

The Obama Administration's Treasury Secretary Timothy Geithner announced on February 10, 2009, the outline of the administration's plans for the use of the second tranche of TARP funds authorized in the EESA, or Tarp 2. ${ }^{39}$ The TARP appellation, and any negative connotations it carried, were dropped by Secretary Geithner in favor of the "Financial Stability Plan." Among other proposals, ${ }^{41}$ the new plan calls for a "stress test" of the nineteen financial institutions whose assets exceed $\$ 100$ billion, with commitments of additional capital to those of the large institutions identified as needing additional capital under the stress test scenarios. These institutions account for approximately two-thirds of all bank holding company assets. ${ }^{42}$

The stress test is sometimes referred to as the "Forward-Looking Capital Assessment," and the "Supervisory Capital Assessment Program.,"44 The capital assessment requires bank holding companies to predict their losses over the next two years under two different economic scenarios: a "baseline" scenario that is supposed to mirror the consensus view about the length and severity of the recession ${ }^{45}$ and a "more adverse" scenario assuming a longer and more severe recession. ${ }^{46}$ Some observers worry, however, that the more adverse scenario "may not be dire enough" since it assumes: only a $3.3 \%$ contraction in the economy in 2009 with no additional contraction in 2010; that unemployment will hit $8.9 \%$ in 2009 and $10.3 \%$ in 2010 ; and that housing prices will lose $22 \%$ in 2009. ${ }^{47}$ Moreover, each covered financial institution carries out its own analysis under government supervi-

39 Secretary Geithner Introduces Financial Stability Plan, Feb. 10, 2009, available at http://www.treasury.gov/press/releases/tg18.htm.

$40 \quad I d$. ("[W]e will replace the current program with a new Financial Stability Plan to stabilize and repair the financial system, and support the flow of credit necessary for recovery . ...").

41 The other pillars of the Financial Stability Plan include a Public-Private Investment Fund which "provide[s] government capital and government financing to help leverage private capital" and to get markets working again by purchasing loans and assets that are burdening the balance sheets of financial institutions; a commitment of up to $\$ 1$ trillion to support a Consumer and Business Lending Initiative built on the Federal Reserve's Term Asset Backed Securities Loan Facility to restart the securitization markets for small business lending, consumer and auto loans, student loans, and commercial mortgages; and the establishment of a housing program to bring down mortgage payments and reduce mortgage interest.

42 FAQs - Supervisory Capital Assessment Program Q2 [hereinafter "Capital Assessment FAQs"], available at http://www.fdic.gov/news/news/press/2009/pr09025a.pdf.

43 White Paper, infra note 51, at 2.

44 Capital Assessment FAQs, supra note 42.

45 Capital Assessment FAQs, App., supra note 42.

46 Id.

47 Editorial, Stress-Testing the Banks, N.Y. TIMES, Mar. 2, 2009 available at http://www.nytimes.com/2009/03/02/opinion/02mon1.html?_r=1\&scp=2\&sq=stress\%20testing\%20the $\% 20$ banks\&st $=$ cse. 
sion. ${ }^{48}$ Concerned observers worry that banks' incentives to minimize the capital they need may skew test results. ${ }^{49}$ The stress tests were completed by the end of April 2009 with banks afforded the opportunity to challenge the results before they are made public in early May 2009.Federal banking regulators, following discussions with the nineteen financial institutions, will determine whether each institution's capital is sufficient given the results of the stress tests.

The new vehicle for equity investments in bank stock in the Financial Stability Plan is the Capital Assistance Program (CAP). ${ }^{51}$ If the stress indicates a need for additional capital, the bank may try to raise private capital to fill the gap. If private capital cannot be raised in six months, then the bank may get the capital from the government's lcommitment to issue a new CAP convertible preferred security to the Treasury in the amount required.

The Joint Press release of the federal banking regulators of February 23, 2009, notes two purposes for CAP: "to preserve the viability of systemically important financial institutions so that they are able to meet their commitments," and to "ensure that banks have the capital and liquidity they need to provide the credit necessary to restore economic growth."53 Banking institutions other than the largest nineteen that have been subjected to the stress testing may also access CAP "to increase capital buffers as necessary." ${ }^{, 54}$ Moreover, any banking organization that is a participant in the CPP may, with supervisory approval, exchange the TARP preferred stock for the CAP security.

The CAP security is a preferred security that may be converted into common equity - contingent common capital - if conversion is needed to maintain investor confidence or to meet the expectations of regulators about

\footnotetext{
$48 \quad I d$.

49 Id.

50 Capital Assessment FAQs, Q3 \& Q6, supra note 42.

51 U.S. Treasury, The Capital Assistance Program and its role in the Financial Stability Plan, Feb. 25, 2009 [hereinafter "White Paper"], available at http://www.treasury.gov/press/releases/reports/tg40_capwhitepaper.pdf; U.S. Treasury, Summary of Mandatorily Convertible Preferrred Stock ("Convertible Preferred") Terms, Feb. 25, 2009 [hereinafter "CAP Term Sheet"], available at http://www.treasury.gov/press/releases/reports/tg40_captermsheet.pdf; U.S. Treasury, Capital Assistance Program FAQs, Feb. 25, 2009 [hereinafter "CAP FAQs"], available at http://www.treasury.gov/press/releases/reports/tg40_cap_faq.pdf.

52 Capital Assessment FAQs, Q10, supra note 42.

53 Joint Statement by the Treasury, FDIC, OCC, OTS, and the Federal Reserve, Feb. 23, 2009, available at http://www.federalreserve.gov/newsevents/press/bcreg/20090223a.htm.

54 White Paper, supra note 40, at 3 \& n.2. See also Bonnie McGeer \& Marissa Fajt, Healthy Firms Worry Treasury Capital Now Tainted, AM. BANKER, Mar. 2, 2009 (discussing concern among bankers that the capital program "was billed last fall as a way to spur healthy banks to lend more [and] is now seen as assistance for weak banks").

55 White Paper, supra note 51, at 3.
} 
the amount and composition of capital. ${ }^{56}$ The preferred stock automatically converts to common stock after seven years. ${ }^{57}$ The dividend rate on the convertible preferred is nine percent per annum, in excess of the five percent rate for the first three years for the CPP preferred stock and the eight percent rate on the TIP preferred positions in Citigroup and Bank of America. $^{58}$ While the convertible preferred stock is outstanding, dividends on the institution's common stock are limited to one cent per share per quarter unless the Treasury consents to a higher amount. ${ }^{59}$ After conversion to common stock, the Treasury will have the voting rights in the stock. ${ }^{60}$ The Treasury has indicated that it will publish "principles governing its use of these rights" prior to the conversion to common stock. ${ }^{61}$

The incentive for a financial institution to convert from CPP preferred stock to the CAP preferred convertible stock, notwithstanding the higher dividend cost (nine percent instead of five percent), appears to be a potential increase in investor confidence because the preferred stock could be converted into common stock should the institution need additional, tangible common equity. Moreover, while the preferred convertible CAP stock is outstanding, the institution's common stock dividend costs will be limited. A significant dividend reduction will increase retained earnings and capital, ${ }^{62}$ but could that could also be accomplished by the institution at its own volition and without government mandate.

The new emphasis on tangible common equity (TCE) is also apparent in the Treasury's announcement on February 27, 2009, that, at Citigroup's request, it would convert up to its initial \$25 billion in CPP preferred stock to common stock on a dollar-for-dollar basis with other private preferred stockholders. ${ }^{63}$ The advantages to Citigroup of this conversion are that it will no longer need to pay a five percent dividend to the Treasury for the preferred stock. In addition, Citigroup's TCE will increase by the amount of the preferred stock converted. Some market participants view tangible common equity as a better measure of an institution's health than its Tier 1 Capital or Total Capital ratios. ${ }^{64}$ TCE is a ratio based on an institution's common stock to its total assets. The Tier 1 Capital raio is based on an

56 White Paper, supra note 51, at 3.

57 CAP Term Sheet, supra note 51, at 3.

8 CAP Term Sheet, supra note 51, at 4.

CAP Term Sheet, supra note 51, at 4-5.

Id. at 5 .

Id.

62 See Warren Buffett on Wells Fargo (Interview by Adam Lashinsky), Apr. 20, 2009, http://cnnmoney.com (Noting that Wells Fargo has voluntarily cut its dividend rate by $85 \%$ and "will be piling up equity while they're paying nominal dividends.").

63 Department of Treasury, Press Release, Treasury Announces Participation in Citigroup's Exchange Offering, Feb. 27, 2009 (hereafter "Citi Exchange Offering Press Release"), available at http://www.treas.gov/press/releases/tg41.htm.

64 Cheyenne Hopkins, Citi Converts Tarp Funds to Common Stock, AM. BANKER, Feb. 27, 2009. 
institution's core capital divided by its risk-adjusted assets. By adjusting assets based on their risk, it is a more finely tuned ration than TCE. But, Tier 1 Capital includes as core capital some items in addition to common equity, including noncumulative perpetual preferred stock and minority interests in consolidated subsidiaries. ${ }^{65}$ The Total Capital ratio is also based on risk-adjusted assets, but is calculated by adding Tier 2 Capital to the Tier 1 Capital amount. Tier 2 capital includes other long-term funding sources such as cumulative perpetual preferred stock, long-term preferred stock, convertible preferred stock, some subordinated debt instruments, and the allowance for loan and lease losses. ${ }^{66}$ Thus, it appears likely that the CPP and CAP preferred stock would be classified as Tier 2 capital for purposes of calculating an institution's Total Capital ratio. In most cases, one would expect the Total Capital ratio to be the highest ratio, followed by the Tier 1 Capital ratio, and then the TCE. To the extent the stress test looks to TCE, ${ }^{67}$ this conversion of Citicorp's CAP preferred stock to common equity may have been necessary to assure that Citigroup does not fail the stress test. ${ }^{68}$ Citigroup announced that in connection with this exchange it was suspending its dividend payments to its preferred and common shareholders. ${ }^{6}$

The conversion of preferred stock to common stock dilutes Citigroup's existing common shareholders, but also removes preferred stockholders and their ability to be paid before common shareholders in a liquidation proceeding. $^{70}$ This new focus on TCE is curious since the conversion of CAP preferred stock to common equity to bolster TCE does not increase the government's investment in Citigroup or provide any new capital to Citigroup. The conversion just rearranges the composition of Citigroup's capital among the various capital elements. If this increase in common equity quells market fears about the adequacy of Citigroup's capital, the conversion, although dilutive, may ultimately inure to the benefit of the preexisting common shareholders. ${ }^{71}$ The government may view this more as pro-

6512 C.F.R. pt. 225, App. A.

66 Id.

67 Eric Dash, Stress Test for Banks Exposes Rift on Wall St., N.Y. TIMES, Feb. 25, 2009, available at http://www.nytimes.com/2009/02/25/business/economy/25bank.html?scp=1\&sq=stress $\% 20$ test

$\% 20$ for $\% 20$ banks $\% 20$ exposes $\% 20$ rift $\% 20$ on $\% 20$ wall\%20st\&st=cse.

68 Paul Davis \& Matthew Monks, Price Would Be Key Call in Citi Stock Conversion, AM. BANKER, Feb. 24, 2009 (quoting a market analyst as saying, "[w] hat the government is trying to do, in a creative way, is get Citibank in a position where is would actually pass the stress test.").

69 Cheyenne Hopkins, Citi Converts Tarp Funds to Common Stock, AM. BANKER, Feb. 27, 2009. One might ask whether the dividend suspension was designed to encourage non-U.S. Treasury preferred shareholders to convert to common stock or whether it was necessary to reduce the dividend cost.

70 Deborah Solomon \& David Enrich, U.S. to Take Big Citi Stake and Overhaul the Board, WALL ST. J., Feb. 27, 2009, available at http://online.wsj.com/article/SB123570659457790823.html.

71 Eric Dash \& Louise Story, Latest Citigroup Rescue May Not Be Its Last, N.Y. TIMES, Feb. 28, 2009, available at http://www.nytimes.com/2009/02/28/business/28citi.html?scp=1\&sq=latest

$\% 20$ citigroup $\% 20$ rescue $\% 20$ may $\% 20$ not $\% 20$ be $\% 20$ the $\% 20$ last $\&$ st $=$ cse. 
viding a benefit to Citigroup (through a higher TCE) without additional cost to the government or appropriation of additional TARP funding. The injection of the government as a shareholder of common stock in Citigroup (or in institutions that convert CAP preferred convertible stock to common stock) raised concerns about government nationalization, which will be discussed later in this article. Indeed, the exchange price appears to have been set at a relatively high rate, perhaps to ensure that the government's percentage share of Citigroup's common stock is not a majority interest. ${ }^{72}$

\section{American Recovery and Reinvestment Act (ARRA) and Conditions Imposed on TARP Recipients}

The American Recovery and Reinvestment Act of 2009 (ARRA), signed by President Obama on February 17, 2009 -- the stimulus bill -placed substantial conditions on TARP recipients that will apply to recipients of government investments under the new CAP program as well. ${ }^{73}$ EESA originally placed some limits on executive compensation at institutions receiving government assistance. ${ }^{74}$ The three major features of the EESA on executive compensation were to require review of the compensation arrangements of the top five executives and a certification that their compensation packages do not encourage excessive and unnecessary risktaking; to limit golden parachute payments to the top five executives to three times their base amounts under section $280 \mathrm{G}$ of the Internal Revenue Code; and to require that any incentive compensation paid to the top five executives be subject to a "clawback" in the event the financial statements on which the compensation was based were subsequently found to be materially inaccurate. ${ }^{75}$ Public outrage over payment of bonuses at Merrill Lynch just prior to consummation of its merger with Bank of America, and other compensation to executives that seemed excessive in the light of losses suffered by their institutions and employee layoffs at their institutions, spurred the Treasury Department to announce additional executive compensation restrictions applicable to institutions receiving federal assistance on February 4, 2009..$^{76}$ Most of these new guidelines were superseded by the ARRA, which was enacted less than two weeks later.

72 U.S. Department of the Treasury, Transaction Outline [hereafter "Citi Exchange OfferingTerm Sheet"], available at http://reas.gov/press/releases/reports/transaction_outline.pdf. The remaining Citigroup preferred stock held by Treasury under the TIP, amounting to $\$ 20$ billion, will be converted to a trust preferred security that will carry the same $8 \%$ cash dividend as the current preferred stock. Citi Exchange Offering Press Release, supra note 63.

73 H.R. 1 (hereinafter"ARRA"), available at http://frwebgate.access.gpo.gov/cgibin/getdoc.cgi ?dbname=111_cong_bills\&docid=f:h1enr.pdf.

74 EESA, $\S 111$ (codified at 12 U.S.C.A. $\$ 5221$ ).

75 Id.

76 Department of the Treasury, Press Release, Treasury Announces New Restrictions on Executive Compenation, TG-15, Feb. 4, 2009, available at http://www.ustreas.gov/press/releases/tg15.htm. 
ARRA amends EESA's executive compensation restrictions and applies the new restrictions retroactively to those institutions that have already received TARP funds as well as prospectively to recipients of new forms of government assistance. ${ }^{77}$ ARRA prohibits bonuses, retention awards, or other incentive compensation, except for restricted stock awards. ${ }^{78} \mathrm{Re}-$ stricted stock, however, is limited in amount to less than one-third of an employee's annual compensation and may not fully vest until after the TARP obligation is repaid. ${ }^{79}$ The number of an institution's employees that are subject to these limits depends on the amount of government assistance received by the institution. ${ }^{80}$ The highest number of affected employees is twenty-five, and that applies to any institution that has received $\$ 500$ million or more in assistance from the government. ${ }^{81}$ Employees with employment contracts entered into before February 11, 2009, entitling them to incentive compensation, are grandfathered in and may receive that compensation. $^{82}$ The EESA restrictions on golden parachutes were expanded to cover the ten highest paid employees, and the clawback provision was expanded to include the twenty-five highest paid employees. ${ }^{83}$ Furthermore, prior compensation and bonuses of the top twenty-five employees must be reviewed by Treasury to determine whether any payments were inconsistent with the ARRA standards or otherwise contrary to the public interest. ${ }^{84}$ If so, the Treasury must negotiate with the financial institution and the employee for reimbursement of the funds to the government. ${ }^{85}$ Finally, responding to notable lapses of judgment by financial institutions receiving government assistance, ARRA requires that each TARP recipient establish a policy on excessive or luxury expenditures. ${ }^{86}$ The expenditures to be addressed include events, entertainment, office renovations, and planes or other transportation services. ${ }^{87}$

77 The statute covers "TARP recipients" which are defined to include "any entity that has received or will receive financial assistance under the financial assistance provided under the TARP." ARRA, § 7001 (codified at 12 U.S.C.A. $§ 5221(\mathrm{a})(3)$ ).

78 ARRA, § 7001 (codified at 12 U.S.C.A. $\$ 5221(\mathrm{~b})(3)(\mathrm{D})(\mathrm{i})$ ).

79 ARRA, $\$ 7001$ (codified at 12 U.S.C.A. $\$ 5221(\mathrm{~b})(3)(\mathrm{D})(\mathrm{i})(\mathrm{I}-\mathrm{II})$ ).

80 ARRA, $\$ 7001$ (codified at 12 U.S.C.A. $\S 5221(\mathrm{~b})(3)(\mathrm{D}(\mathrm{ii})$ ).

81 ARRA, § 7001 (codified at 12 U.S.C.A. § 5221(b)(3)(D)(ii)(IV)). The number of affected employees includes the "senior executive officers" and the next twenty most highly compensated employees. "Senior executive officer" includes the top five most highly paid employees of a public company whose compensation must be disclosed under the Securities Exchange Act of 1934. Id. (codified at 12 U.S.C.A.§ 5221(a)(1)).

82 ARRA, $\$ 7001$ (codified at 12 U.S.C.A. $§ 5221(\mathrm{~b})(3)(\mathrm{D})(\mathrm{iii})$ ).

83 ARRA, § 7001 (codified at 12 U.S.C.A. $\$ 5221$ (b)(3)(B) \& (C)).

84 ARRA, § 7001 (codified at 12 U.S.C.A. § 5221(f)(1)).

85 ARRA, § 7001 (codified at 12 U.S.C.A. \$ 5221(f)(2)).

86 ARRA, $\$ 7001$ (codified at 12 U.S.C.A. § 5221(d)).

87 Id. 
The Treasury Department is to issue regulations implementing these new statutory provisions as soon as practicable. ${ }^{88}$ The regulations will hopefully clarify whether the Treasury's Guidelines on Executive Compensation announced on February 4, 2009, most of which are specifically superseded by ARRA, still apply with respect to the announced $\$ 500,000$ limit on compensation (other than restricted stock) to senior executives of institutions receiving TARP assistance.

Institutions unwilling to play by these new, and some would say more onerous, rules are permitted to prepay their TARP assistance to the Treasury if approved by the Treasury and the institution's regulator. ${ }^{89}$ A number of institutions have indicated that because of these additional restrictions they are seeking government permission to repay their TARP investments." TARP investments may be repaid under this provision, amending EESA, even if the funds are not replaced by private capital. ${ }^{91}$

\section{E. Budget Placeholder for Additional TARP Funds}

President Obama's first budget, unveiled on February 25, 2009, contains a $\$ 250$ billion placeholder for government losses associated with its bank investments. ${ }^{92}$ The amount assumes that Congress authorizes $\$ 750$ billion in additional funds to provide support for financial institutions, but is only repaid two-thirds of its investment, leaving a $\$ 250$ billion cost. $^{93}$ It is possible, of course, that the administration will not need to ask Congress for additional funding, but President Obama decided that it was important to acknowledge the possibility of this additional cost. ${ }^{94}$

\section{GOVERnMENT INVESTMENT IN BANK STOCK DURING PRIOR CRISES}

This section discusses the implications of government investment in banks by first reviewing prior government ownership of bank stocks. During the Great Depression, the Reconstruction Finance Corporation (RFC) purchased stock in forty percent of all banks, ${ }^{95}$ and in 1984 the government became the major shareholder of Continental Illinois National Bank. After analyzing these government investments, this Part will explore some of the

\footnotetext{
88 ARRA, § 7001 (codified at 12 U.S.C.A. § 5221(h)).

89 ARRA, § 7001 (codified at 12 U.S.C.A. § 5221(g)).

90 Stephen Labaton, Some Banks Feeling Chained, Want to Return Bailout Money, N.Y. TiMES, Mar. 18, 2009.

91 ARRA, § 7001 (codified at 12 U.S.C.A. § 5221(g)).

92 Maya Jackson Randall \& Meena Thiruvengadam, Government Sets 'Placeholder' for More Bank Losses, Wall ST. J., Feb. 27, 2009, at A4.

93 Id.

94 Id.

95 William R. Keeton, The Reconstruction Finance Corporation: Would It Work Today?, ECON. REV. (Fed. Res. Bank of Kansas City, $1^{\text {st }}$ Q. 1992), at 39, available at http://www.kc.frb.org/PUBLICAT/ECONREV/EconRevArchive/1992/1Q92KEET.pdf.
} 
implications of the current, extraordinary government investment in banks and bank holding companies.

\section{A. Reconstruction Finance Corporation (1932 - 1957)}

Congress created the Reconstruction Finance Corporation (RFC) in January 1932. Its original purpose was to make loans to banks, along with railroads and state and local governments. In March 1933, the Emergency Banking Act authorized the RFC to purchase preferred stock in banks "in need of funds for capital purposes either in connection with the organization or reorganization of such [banks]." ${ }^{96}$ The RFC was directed to invest only in "sound" banks, but had broad discretion to determine what constituted a sound institution. The preferred stock carried voting rights and had a 10year maturity, but was not convertible to common stock and was not accompanied by warrants to purchase stock. ${ }^{97}$ RFC investments often meant new executive officers and directors, and reduction in salaries of senior bank officials, ${ }^{98}$ although RFC officials contended that only once did the RFC nominate a specific individual over the objection of the current directors. 99

The preferred stock purchase program got off to a slow start. Those banks that reopened after the nationwide bank holiday expressed little interest. $^{100}$ Some banks feared that participation in the program might be interpreted as a sign of financial weakness. Banks also may have been concerned about making the dividend payments required on the preferred stock. ${ }^{101}$ The Roosevelt administration encouraged banks to participate in the program so that they would be able to meet the solvency prerequisite for federal deposit insurance, then a new program created by Congress in June 1933, and to commence on January 1, 1934. ${ }^{102}$ RFC investment increased substantially in late 1933 in response to this White House pressure and remained high through the first half of $1934 .^{103}$ Over the course of the next year, RFC investment slowed and healthier banks began retiring their obli-

96 BD. OF Governors, U.S. Fed. RES. Sys., 19 FED. RES. BuLl. 117 (1933) (quoting Section 304 of the Emergency Banking Act). Some state banks were prohibited from selling the preferred stock authorized by the legislation, so Congress amended the law shortly after its enactment to permit the RFC to also purchase subordinated debt. Keeton, supra note 92, at 38-39.

97 Keeton, supra note 95, at 49.

98 Walker F. Todd, History of and Rationales for the Reconstruction Finance Corporation, ECON. REV., 4th Quarter 1992, at 26 (Fed. Reserve Bank of Cleveland), available at http://www.clevelandfed.org/research/review/1992/92-q4-todd.pdf.

99 Cyril B. Closed AND Distressed BANKS 238-39 \& n.22 (1934).

100 Keeton, supra note 95, at 39.

101 Id.

102 Keeton, supra note 95, at 39.

103 Id. at 39, 40 (Chart 1). 
gations, reducing the amount of RFC capital outstanding. ${ }^{104}$ The RFC committed a total of $\$ 1.2$ billion to the preferred stock purchase program, and in June 1935, held $\$ 892$ million in bank capital. ${ }^{105}$ New bank investment by the RFC effectively ended by the close of 1935 . Notwithstanding the large infusion of RFC capital, total bank lending continued to stagnate and was just as weak at banks with high RFC capital as at banks with low RFC capital. $^{106}$

Milton Friedman observed that the RFC "played a major role in the restoration of the banking system." "107 Jesse Jones, the head of the RFC for thirteen years, commented: "This program of putting capital into banks prevented the failure of our whole credit system." 108 He continued:

If the system as a whole had not been assisted by the injection of a large amount of new capital into about one-half of all banks in the country, the collapse would have become so widespread that few, if any, banks could have continued operating. ${ }^{109}$

Moreover, following the preferred stock injections that began in 1933, there was a sharp decline in bank failures from an average of $10.7 \%$ per year from $1930-1933$ to $0.4 \%$ per year from 1934-1940. ${ }^{110}$ Banks receiving RFC capital, however, failed at a higher rate than banks that did not receive RFC capital, perhaps because some nonviable banks received RFC capital. ${ }^{11}$ Nevertheless, "while the RFC may have propped up some nonviable banks that later failed, it may have rescued an even greater number of viable banks that later recovered."

The United States government essentially broke even on its RFC investments, ignoring the time value of money. ${ }^{13}$ After 1935, banks steadily repaid their RFC preferred stock investments to the government, and, by the end of 1947, only $\$ 146$ million remained on the banks' books out of a total government investment of $\$ 1.2$ billion. $^{114}$ The RFC charged-off only $\$ 11$ million from 1933 to $1947 .{ }^{115}$ Repayments continued until the agency was

104 Id. at 39.

105 Keeton, supra note 95, at 39, 41.

106 Keeton, supra note 95, at 39 n.20.

107 Milton Friedman \& AnNa Schwartz, A Monetary History of the United States 18671960427 (1963).

108 JESSE JONES, FifTy BILliON DOLLARs 26 (1951)

109 Id. at 34.

110 Keeton, supra note 95, at 38 (Table 1), 40-41.

111 See id. at 42.

112 Id. at 42.

113 Todd, supra note 98, at 31.

114 Keeton, supra note 95, at 40-41.

115 Id. at 41. 
abolished in 1957 with less than $\$ 5$ million in two banks remaining unpaid. $^{116}$

B. Continental Illinois National Bank (1984 - 1991)

Government investment in a single bank in 1984, Continental Illinois National Bank in Chicago - then the nation's seventh largest bank and the largest commercial and industrial bank ${ }^{117}$ - demonstrates the public dissatisfaction and political fallout that ensued from government stock ownership. Continental faced a run from depositors in part as the result of its $\$ 1$ billion purchase of participations in speculative oil and gas exploration loans from PennSquare Bank, N.A. of Oklahoma which subsequently failed. The government intervened and provided a package of extraordinary interventions for Continental, fearful that its failure would result in the failure of a number of other financial institutions. Approximately 2,300 correspondent banks had funds on deposit at Continental Illinois. ${ }^{118}$ Over forty-two percent of those banks had deposits in excess of the $\$ 100,000$ deposit insurance limit. $^{119}$ The uninsured deposits of correspondent banks amounted to almost $\$ 6$ billion. ${ }^{120}$ Moreover, sixty-six of the correspondent banks, with total assets of almost $\$ 5$ billion, had amounts equal to over $100 \%$ of their equity capital on deposit at Continental, while another 113 banks, with total assets of over $\$ 12$ billion held amounts on deposit at Continental equaling between fifty and one hundred percent of their equity capital. ${ }^{121}$

Among the government interventions was the FDIC's acquisition of \$1 billion in preferred stock in Continental Illinois Corporation (CIC), which the holding company was obligated to transfer to the bank as equity. ${ }^{122}$ The investment in the holding company stock rather than the bank's stock was necessary because outstanding indenture agreements with the holding company prevented a direct investment in the bank subsidiary. ${ }^{123}$ The holding company investment was controversial because it served to cushion holding company bondholders from loss. ${ }^{124}$

116 U.S. TREASURy DEP'T, FinAl REPORT ON THE RECONSTRUCTION FINANCE CORPORATION 176 (Government Printing Office 1959).

117 Lee Davison, FDIC, "Continental Illinois and "Too Big to Fail," History of the Eighties -Lessons for the Future, ch. 7 (1997) 236, available at http://www.fdic.gov/bank/historical/history/235_258.pdf.

$118 \mathrm{Id}$. at 250.

119 Davison, supra note 117 , at 250.

120 Id.

121 Id.

122 Davison, supra note 117, at 244.

123 Id.

124 John Riley, Inside the Bailout: Continental Leaves a Wide Wake, NAT'L LAW J., Oct. 22, 1984, at 29 . 
The FDIC purchased $\$ 720$ million of permanent, convertible, nonvoting, junior preferred stock and \$280 million of permanent, adjustable rate, cumulative preferred stock. ${ }^{125}$ Pursuant to the terms of the government assistance, the senior management and board of directors of Continental Illinois were replaced. ${ }^{126}$ The FDIC took seven years to completely divest itself of its Continental shares by gradually selling its stake in the market. The first sale occurred two years after the implementation of the bailout in December 1986. ${ }^{127}$ Subsequent sales occurred in December 1988 and August 1989, with a final sale in June 1991. ${ }^{128}$ At the time of each sale of the convertible stock, it was converted to common stock. ${ }^{129}$ The FDIC realized a net gain of $\$ 200$ million in excess of its $\$ 1$ billion investment. ${ }^{130}$

The FDIC's stake in Continental constituted eighty percent ownership, and the FDIC's assistance package was frequently characterized as nationalization of the bank, even though the FDIC shares did not contain voting rights. In any event, the combination of assistance provided to Continental - FDIC insurance guarantee to all depositors and creditors, the possibility that Continental shareholders might retain some value from their investment rather than being wiped out by the bank's insolvency, and the substantial protection of the holding company's bondholders - resulted in substantial criticism. ${ }^{131}$ The widely held belief was that the FDIC had determined that some institutions were "too big to fail,", 132 while others were not, creating "a significant inequity in the deposit insurance system." 133

Ultimately, Congress required in the Federal Deposit Insurance Corporation Improvement Act of 1991 (FDICIA) that the FDIC use the "least cost resolution" method in resolving an insolvent bank; although, the FDICIA provided a systemic risk exception from that requirement to permit assis-

125 FDIC, “Continental Illinois National Bank and Trust Company," Ch. 4 (1997) 545, 556, available at $\mathrm{http} / / / \mathrm{www} . \mathrm{fdic} . \mathrm{gov} / \mathrm{bank} / \mathrm{historical} /$ managing/history2-04.pdf.

126 Davison, supra note 117, at 244-45.

127 “Continental Illinois National Bank and Trust Company," supra note 127, at 557.

128 Id.

129 Id.

130 Id. The preferred stock purchases were part of a larger package of governmental assistance. The total estimated cost to the FDIC of its involvement in resolving Continental Illinois was approximately $\$ 1.1$ billion, a figure which was substantially less than the costs it incurred for the resolution of other failed banks, such as First RepublicBank Corp. ( $\$ 3.77$ billion) and MCorp-Dallas ( $\$ 2.85$ billion). Davison, supra note 117, at 245 n.37.

131 Davison, supra note 117, at 248.

132 Carrie Stradley Lavargna, Government-Sponsored Enterprises Are "Too Big to Fail": Balancing Public and Private Interests, 44 HASTINGs L.J. 992, 1011-13 (1993).

133 Davison, supra note 120, at 248; see FDIC, Failed Bank Cost Analysis 1986-1995 (1996), 11 (noting the correlation between bank size and resolution method: the average asset of size of institutions that were resolved by insured-deposit payoff and liquidation between 1986 and 1991 was approximately $\$ 65$ million, while the average asset size of institutions that were resolved during the same time period through either acquisition or open bank assistance, both of which meant uninsured depositors were protected, was about $\$ 200$ million). 
tance, including open bank assistance, if the institution's failure would have "serious adverse effects on economic conditions or financial stability."

\section{EVALUATING GOVERNMENT INVESTMENT IN BANKS}

This Part evaluates government investment in banks first through the lens of the RFC and the Continental Illinois experience. Next, implications of the current government investment regime are highlighted.

\section{A. Through an Historical Lens}

\section{Comparisons with the RFC Preferred Stock Investments}

The success of the RFC was cited by Senator Charles Schumer and others as Congress was considering passage of the EESA in $2008 .^{135}$ The initial focus of the EESA seemed to be the government purchase of the troubled assets (loans) held by banks, but Schumer argued that this would not do enough to buttress bank capital and proposed recreating the RFC to "provide capital to struggling financial institutions in exchange for an equity stake.",136

The RFC preferred stock purchases are similar in many respects to the government's CPP purchase program. The stock issue was preferred stock. The RFC had the discretion to determine which institutions would receive the stock and no doubt they included some nonviable banks in that mix. As with the RFC investments, some banks were reluctant to participate in the CPP program for fear of showing financial weakness to their customers and investors. Nevertheless, a substantial portion of bank capital was held by the government. Banks that did take the investments had a strong interest in retiring the government's stake as soon as feasible. The government investments did not necessarily spur additional lending, but rather may have provided assistance to banks that might have otherwise failed. Salaries of bank employees were under scrutiny and sometimes reduced.

13412 U.S.C. $\S 1823(\mathrm{c})(4)(\mathrm{G})(2006)$.

135 Sen. Charles E. Schumer, Remarks on the Senate Floor (Sept. 18, 2008), available at http://schumer.senate.gov/SchumerWebsite/pressroom/record.cfm?id=303245. Others expressing similar views included, Nouriel Roubini, Professor of Economics and International Business at New York University's Stern School of Business, Nouriel Roubini, Our Choice, ForBES, Oct. 9, 2008, http://www.forbes.com/opinions/2008/10/08/recession-depression-keynes-oped-

cx_nr_1009roubini.html; George Soros, Chairman, Soros Fund Management, George Soros, Recapitalise the banking system, FinANCIAL TimeS, Oct. 1, 2008, http://www.ft.com/cms/s/0/d68e10cc-8f4511dd-946c-0000779fd18c.html; and Paul Krugman, Professor of Economics and International Affairs at Princeton University, Paul Krugman, Cash for Trash, N.Y. TIMES, Sept. 21, 2008, http://www.nytimes.com/2008/09/22/opinion/22krugman.html.

136 Sen. Charles E. Schumer, Remarks on the Senate Floor (Sept. 18, 2008), available at http://schumer.senate.gov/SchumerWebsite/pressroom/record.cfm?id=303245. 
There remain some notable differences. The RFC had voting rights attached to its preferred stock, but did not receive warrants to purchase common stock or have the right to convert the preferred stock into common stock. The government's current preferred stock investments do not carry voting rights, but upon conversion of the CAP convertible preferred to common stock, the Treasury will have voting rights. Observers of the RFC were concerned about the government's use of its voting powers, but as previously explained each institution ultimately paid back its RFC investment and regained its status as a wholly privately owned entity. The Brookings Institution published a book in 1934 recounting the contemporary concerns with the government exercising voting power over bank stocks.

[D]irect ownership of equities and participation in the management of individual banks, is a new thing in American banking history. Government ownership has never been accepted or even made a serious political issue. But almost without realization by the public, the government has established in the RFC the largest bank in the world and through it the government now has a substantial voting interest in half the commercial banks of the nation. ... Inasmuch as it owns half the stock of most of the reorganized national banks, [the RFC] is obviously in a position to exert substantial control over their management. ${ }^{137}$

In response to this critique, the Chairman of the RFC repeatedly noted:

the government has, and has had, only two objective in view in its preferred stock program. One to strengthen the banks in the interests of depositors, and the other to place banks in such a strong capital position as to engable them to assist in the recovery program by providing legal credit for agriculture, business, and industry.

There is no thought of dictating management nor of coercion as to bank policies or bank investment. ${ }^{138}$

The RFC preferred stock investments may have helped weak banks reassure uninsured depositors about the safety of their funds. The initial limit on deposit insurance was $\$ 2,500$, which meant that only one-third of all bank deposits were insured, although this percentage increased to fortyfour percent when the deposit insurance limit was raised to $\$ 5,000$ in the second half of 1934 . $^{139}$ Without the RFC investment, uninsured depositors of troubled banks might have demanded higher interest for their deposits or withdrawn their funds.

137 UPHAM \& LAMKE, supra note 108, at 235.

138 Id. at 238-39 (quoting Address before the New York State Bankers Association, New York City, Feb. 5, 1934).

139 Keeton, supra note 95, at 49 \& n.35.

140 Keeton, supra note 95, at 49. 
This justification for government capital injections is weaker today, when virtually all deposits are at least temporarily covered by deposit insurance, allowing all banks to raise deposits at a low (risk-free) rate of interest. In the EESA, enacted on October 3, 2008, the deposit insurance limit was increased from $\$ 100,000$ to $\$ 250,000$ until December $31,2009 .{ }^{141}$ Less than two weeks later, the FDIC announced on October 14, 2008, that it would provide unlimited deposit insurance to non-interest bearing transaction account holders until December 31, 2009, if a bank elected to seek such coverage, under the Temporary Liquidity Guaranty Program (TLGP). ${ }^{142}$ Moreover, the TLGP also provides FDIC guarantees for certain bank unsecured debt, meant to allow banks to borrow at risk-free rates from non-deposit creditors.

Given the strong similarities between the RFC and the current programs for government investment in bank stock, there is hope that Treasury's investments will be as successful as the RFC's appeared to have been in warding off a failure of the credit market system, decreasing the rate of bank failures, and recovering the government's investment after the banks' return to health. Moreover, the preferred shareholdings of the government do not carry voting rights, although the opportunity for government influence and control is still undeniable. Even if CAP convertible preferred stock is converted to common stock with voting rights, the experience of the RFC might provide some comfort that government voting rights did not unnecessarily complicate the management of the banks in which the government invested.

\section{Comparisons with the Ownership of Continental Illinois}

As noted above, the RFC investments closely mirror the Treasury's CPP program to invest in the preferred stock of financial institutions. The Continental Illinois investment, however, is more similar to the additional TIP investments made in Citigroup and Bank of America, and perhaps to any additional CAP investments made in the nineteen largest financial institutions as the result of their performance on the stress tests. As with Continental Illinois, the government has concluded that additional aid may be needed to protect "systemically significant" institutions, or those formerly known as "too big to fail." The justification for protecting these large institutions is, in part, the same justification used to protect Continental Illinois

141 H.R. 1424, Emergency Economic Stabilization Act of 2008, § 136 (amending 12 U.S.C. § 1821(a)(1)(E) to increase the standard maximum deposit insurance amount from $\$ 100,000$ to $\$ 250,000$ ).

142 Press Release, FDIC, FDIC Announces Plan to Free Up Bank Liquidity, Creates New Program to Guarantee Bank Debt and Fully Insure Non-Interest Bearing Deposit Transaction Accounts (Oct. 14, 2008), available at http:/www.fdic.gov/news/news/press/2008/pr08100.html. This program was authorized under the systemic risk exception. 
- the repercussions of a failure of a very large financial institution would be far-reaching and harm other smaller financial institutions.

The government's ownership stake in Continental Illinois was quite significant. As an owner, it replaced the bank's senior management and its board. Citigroup has shaken-up its board at the request of the government, but so far has not considered replacement of senior management. The government also extended FDIC insurance protection and guarantees to all other depositors and creditors of Continental. In the current crisis, all banks are benefiting from temporarily expanded deposit insurance coverage and unsecured debt guarantees. These benefits have not been limited to the systemically significant financial institutions. The concern about the inequity involved when systemically significant institutions such as Citigroup and Bank of America receive extra relief (and the other seventeen institutions exceeding $\$ 500$ billion in assets may soon receive) when others are allowed to fail continues in today's crisis. As recounted in the Introduction, bank failures are increasing in number and frequency, but so far have been confined to smaller institutions.

In the current crisis, investments were made in holding companies without the explicit requirement that the capital be invested in the bank subsidiary. This led to the rush of financial institutions, such as Goldman Sachs and Morgan Stanley, that previously avoided being characterized as bank holding companies subject to Federal Reserve Board regulation and oversight, seeking to be designated bank holding companies. Indeed, there is some evidence that government capital investments did not necessarily get passed down to the bank subsidiaries where they would be most likely to achieve the purpose of stimulating lending and protecting the solvency of the bank subsidiary. ${ }^{143}$ In the case of Continental Illinois, the holding company was required to transfer its government investment to its bank subsidiary as equity. The lack of such a requirement in our current crisis is curious. Is aid to the holding company by design to keep the holding company and its nonbanking subsidiaries from bankruptcy or did the government fail to make clear its desire that the aid be directed to the bank subsidiary to protect the FDIC from excessive losses from bank failures?

A ray of hope from the government's experience as a major shareholder of Continental Illinois was that it was able to orderly liquidate its owner-

143 See John C. Coates \& David S. Scharfstein, The Bailout Is Robbing the Banks, N.Y. TIMES, Feb. 18, 2009, at A27 (noting that J.P. Morgan Chase, Citigroup, Bank of America, and Wells received $\$ 90$ billion in TARP money in the fall of 2008, but that "by the end of 2008 they had contributed less than $\$ 15$ billion in equity capital to their subsidiary banks"). The authors suggest that holding companies may be reluctant to contribute equity capital to an insolvent bank subsidiary since if the government takes over the insolvent bank, the holding company loses its investment in it. Id. The authors suggest that if the government continues to make investments in bank holding companies, that it require that the investment be directed to subsidiaries - bank and nonbank - that the government explicitly wishes to support. Id. 
ship interest over time without suffering a loss. The government's stakes in Citigroup and Bank of America are in the two largest banks in the United States. It is also not clear what additional investments the government may make in those two institutions or in other systemically significant institutions. It is likely that government divestment of its ownership interests of these larger institutions and more institutions will take longer and may not be on terms as favorable to the government as experienced with Continental Illinois.

\section{B. Implications of the Current Government Investment in Banks}

The purpose of government investment in banks has evolved over time and now seems to include several purposes. Among these, are to provide additional capital to spur increased bank lending, to protect systemically significant financial institutions from failure, and to provide assistance to other institutions so that they will not become insolvent and place further strain on the dwindling FDIC reserves.

To the extent that increasing lending remains an important purpose of the capital investments, it is an objective that faces several obstacles. The first obstacle is the lack of an explicit requirement that the governmentprovided preferred stock investment be down-streamed to the bank subsidiary. ${ }^{144}$ The second obstacle to increased bank lending is that the purchase of preferred stock under the CPP program for those financial institutions that applied and were approved comes at a cost. The dividend due to the government is five percent for the first five years, increasing to nine percent thereafter. Preferred stock issued to Citigroup and Bank of America, pursuant to the TIP program for systemically significant institutions, carries an eight percent dividend; the new CAP convertible preferred stock will earn nine percent. The cost of this source of funds is offset by the lower cost funds that a bank may raise through insured deposits and debt that carries the FDIC's guarantee. Banks must then find lending opportunities that return more than their total cost of funds, ${ }^{145}$ but still meet the safety and soundness requirements expected by bank examiners. Thus, the cost of the preferred stock purchases may induce risky lending behavior by banks rationally seeking a high enough return on loans to offset the bank's cost of funds, including the preferred stock dividend to be paid to the government. At the same time, loan portfolios will be scrupulously examined by bank regulators to ensure prudent lending practices. One implication of the ex-

144 See supra note 151.

145 In the first week of January 2009 , the average rate on a thirty-year home mortgage loan was only $5.01 \%$, declining in the week of January 15 to just $4.96 \%$, and rebounding the week of January 22 to $5.12 \%$. See Freddie Mac, Weekly Primary Mortgage Market Survey, available at

http://www.freddiemac.com/dlink/html/PMMS/display/PMMSOutputYr.jsp (last visited February 8, 2009). 
traordinary government intervention is that the cost of the preferred stock and the caution of bank examiners may result in a standoff in which the new equity does not make its way into increased lending, as was originally anticipated. Increased reporting of loan activity for government-assisted institutions may provide additional incentives for institutions to seek out safe and sound lending opportunities.

To the extent that the dividend costs associated with CPP and CAP stock are viewed as excessive, there is an incentive to seek permission to convert the stock to the lower cost common stock. A second implication of government investments in bank stock is that the possibility of conversion of the government's interest to common stock through the CAP convertible preferred security or a government mandated conversion of CPP preferred stock to common stock may serve to deter private capital investments into banks through new stock issuances or depress the price of existing shares because of the possibility of dilution. On the other hand, existing shareholders may benefit by the addition of more tangible common equity to help absorb the bank's losses. Private capital may find the common stock of the TIP and CAP recipients less attractive, however, because of the TIP and CAP limitation of dividends on common stock to one cent per share per quarter for three years while those preferred stock investments are outstanding.

A third implication of the preferred stock purchases is that the government has an increased interest in the success of the institutions in which it has invested. The Treasury will not be paid its dividend or be repaid its investment upon a repurchase of the stock by the institution if the institution fails. The government's financial stake in the institution could conceivably influence its decision to continue providing assistance to the institution in order to prevent the failure from wiping out its equity interest. This incentive would presumably be greatest where the government has the most to lose - the largest institutions in which its investment is most significant, including Citigroup and Bank of America. A fourth implication is the impact of the government as shareholder on bank management, policies, mergers, and credit decisions. Although its preferred stock may not carry voting privileges, as regulator and owner, the government's influence is likely to be substantial and avoiding conflicts and the appearance of conflicts will be important.

The government will also need to be clear as to when and how a financial institution may buy out the government's interest. The initial limitation on repurchase of the CPP preferred stock was that three years have passed since its issuance and an amount equivalent to the investment is replaced with private capital. ${ }^{146}$ The investment contract signed by each TARP reci-

146 See supra text accompanying note 28. 
pient permits retroactive changes to the contract wto comply with any postclosing changes in federal statutes. ${ }^{147}$ The stimulus bill, ARRA, applied its executive compensation restrictions retroactively to all TARP recipients. ${ }^{148}$ The statute further provides that financial institutions may seek government permission to buy the TARP investments back from the government prior to the initial three-year holding period and without being replaced by private capital. $^{149}$

A number of institutions will likely seek to buy out the government's interest. At least two items, however, are unresolved. First, what is the criteria the government will use in granting peromission to pay it back? Will it be the ability of the particular institution to succeed without the government investment, or will it be, as Treasury Secretary Geithner has suggested, whether the entire financial system is capable of providing adequate credit to the U.S. economy? ${ }^{150}$ A second issue is how CPP recipients may buy back the warrants to purchase common stock that they issued to the government along with its preferred stock. Although in many cases the warrants' exercise price is below the current stock price, the warrants may be exercised over a ten-year period. Determining the present value of the warrants is difficult, and banks complain that requiring them to buy out the government warrants amounts to an onerous prepayment penalty. ${ }^{151}$ Banks argue they should be excused from paying for the warrants in the light of the increasingly onerous TARP conditions, including those on executive compensation.

An interesting by-product of this unprecedented government effort to shore up the ability of banks and their holding companies to borrow and raise capital is the exploding popularity of bank holding companies. The FRB approved the applications of Goldman Sachs, Morgan Stanley, American Express, and General Motors Acceptance Corporation (GMAC), among others, to become bank holding companies, notwithstanding the Bank Holding Company Act's (BHCA) limitations on mixing banking and commerce. Until this financial crisis, all of these institutions assiduously avoided characterization as a bank holding company because of the limitations that designation places on nonbanking and nonfinancial activities of the holding company and because of the desire to avoid the additional regulation and oversight imposed by the FRB under the BHCA. The capital infusions

147 See supra text accompanying note 25.

148 See supra text accompanying note 77.

149 See supra text accompanying notes 89-91.

150 David Cho, Geithner Hints at High Bar in Letting Banks Repay Aid, WASH. Post, Apr. 22, 2009.

151 Damian Paletta \& Deborah Solomon, Financial Firms Lobby to Cut Cost of TARP Exit, WALL ST. J., Apr. 22, 2009, at A2.

152 Id. 
through $\mathrm{CPP},{ }^{153}$ increased deposit insurance and government guarantees, and the public perception that institutions subject to FRB oversight are safer and sounder than less regulated entities, however, have made the bank holding company status quite popular. It remains to be seen what long-term implications these holding companies will present for the continued separation of banking from other commercial enterprises, and whether these firms will gain an unfair advantage over their competitors who have not elected or cannot qualify for bank holding company status.

\section{UNANSWERED QUESTIONS}

While prior government investment in bank stock during the Great Depression and in 1984 in the case of Continental Illinois suggest that the fears of critics of government ownership may be overstated and that the government may ultimately be successful in retuning banks fully to private investors, the discussion does raise a number of concerns and pose many serious questions, whose answers we will have to wait and learn. The Treasury is likely the largest single equity holder of many of the institutions that have qualified for and accepted CPP funds. Does this ownership stake affect the government's decisions about whether to let these institutions fail? Notwithstanding its extensive interest, can the government effectively protect its investment with nonvoting preferred stock? To what extent will institutions exchange their CPP preferred stock for the CAP convertible preferred stock? Will institutions that convert do so at the risk of chilling private capital investors who fear potential dilution if the CAP stock is ultimately converted to common stock? Will substantial restrictions on executive compensation influence banking institutions to redeem their government ownership as soon as possible? How long will it take institutions to increase capital enough to pay back the government investment? To what extent will institutions with significant government investment be subject to political pressure regarding credit and investment decisions? What additional conditions is the government likely to impose on the institutions that have accepted CPP and CAP investments? Will financial institutions be able to pay the preferred stock dividends to the Treasury and the increased deposit insurance assessments to the FDIC, without failing or compromising the safety and soundness of the institution? Will those institutions identified as "systemically significant," a thinly veiled code-name for an institution that is "too big to fail," including Citigroup and Bank of America, be subjected to market discipline or benefit from further government support? The Financial Stability Plan and its forward looking assessment for the nineteen largest bank holding companies, whose assets exceed

153 For a discussion of the fact that relatively little of the CPP investments had been directed to equity in bank subsidiaries, see Broome, supra note 125, at 23; Broome, supra note 137, at 26. 
$\$ 500$ billion, indicate that these institutions, holding two-thirds of all bank holding company assets, are the ones about whose survival the government is most concerned.

Since October 3, 2008, the government has made extraordinary interventions to bolster bank balance sheets and avoid bank failures. Whether these efforts are successful in avoiding widespread bank failure, it is clear that they have dramatically changed the relationship between banks and the government for the foreseeable future. Whether this relationship will be reduced over time, as occurred with the RFC preferred stock and the government's investment in Continental Illinois, where the government investments were fully recouped, remains to be seen. 